\title{
Historical and paleo-tsunami deposits on Kamchatka, Russia: long-term chronologies and long-distance correlations
}

\author{
T. K. Pinegina ${ }^{1}$ and J. Bourgeois ${ }^{2}$ \\ ${ }^{1}$ Institute of Volcanic Geology and Geochemistry, Far-East Division, Russian Academy of Sciences, \\ Petropavlovsk-Kamchatskiy, 683006, Russia \\ ${ }^{2}$ Department of Earth and Space Sciences, University of Washington, Seattle, WA 98195-1310, USA
}

Received: 22 August 2001 - Accepted: 22 October 2001

\begin{abstract}
Along the eastern coast of Kamchatka, at a number of localities, we have identified and attempted to assign ages to deposits of both historic and prehistoric (paleo) tsunamis. These deposits are dated and correlated using tephrochronology from Holocene marker tephra and local volcanic ash layers. Because the historical record of earthquakes and tsunamis on Kamchatka is so short, these investigations can make important contributions to evaluating tsunami hazards. Moreover, because even the historical record is spotty, our work helps add to and evaluate tsunami catalogues for Kamchatka. Furthermore, tsunami deposits provide a proxy record for large earthquakes and thus are important paleoseismological tools. The combined, preserved record of tsunami deposits and of numerous marker tephra on Kamchatka offers an unprecedented opportunity to study tsunami frequency. Using combined stratigraphic sections, we can examine both the average frequency of events for each locality, and also changes in frequency through time. Moreover, using key marker tephra as time lines, we can compare tsunami frequency and intensity records along the Kamchatka subduction zone. Preliminary results suggest real variations in frequency on a millennial time scale, with the period from about 0 to 1000 A.D. being particularly active at some localities.
\end{abstract}

\section{Introduction}

The Kamchatka Peninsula (Fig. 1) is one of the most tectonically active regions of the world, and has historically experienced a number of large tsunamis generated along the Kamchatka-Kuril subduction zone (Soloviev and Go, 1974; Zayakin and Luchinina, 1987; Zayakin, 1996; see also online tsunami databases). The two largest of these occurred in November 1952, and in October 1737; the latter is the oldest historically documented tsunami on Kamchatka. Catalogu-

Correspondence to: J. Bourgeois

(jbourgeo@u.washington.edu) ing and assessing tsunami records are important for longterm tsunami prediction and for tsunami-hazard mapping. In the case of Kamchatka, however, as well as a number of other tsunami-susceptible coastlines, historical records of tsunamis are too short to develop a predictive chronology of events using only historical data. The way to obtain long-term data is to study paleotsunamis, that is, to identify, map and date prehistoric tsunami deposits. These deposits also provide a proxy record of large earthquakes.

Paleotsunami research became an active field of investigation in the late 1980s (e.g. Dawson et al., 1991; see Dawson and Shi, 2000, for recent literature review). Evidence of strong modern and pre-historic earthquakes and tsunamis has been found and studied in Japan, North America, and a number of other localities (e.g. Minoura et al., 1994; Benson et al., 1997; and others). On Kamchatka, studies of tsunami deposits began in about 1990 (e.g. Melekestsev et al., 1994; Minoura et al., 1996; Pinegina et al., 1997). In the course of these studies, techniques have been developed for identifying paleotsunami deposits, but none, to our knowledge, outside of Kamchatka has generated statistics for millennial-scale paleotsunami distribution and frequency. In most studied regions, long-term statistics are unobtainable because there are too few recorded events, or a scarcity of reliably dated events, or a lack of means for correlation of events in different localities.

The eastern coast of Kamchatka, downwind of one of the most active volcanic arcs in the world, offers a superb opportunity to examine millennial-scale records of tsunami history. The tephra from these volcanoes have been studied for the last 50 years (e.g. Braitseva et al., 1997), and widespread occurrence of key-marker tephra permits dating and correlation of sections bearing tsunami deposits. Because no one section will preserve all tsunami deposits or tephra, multiple sites, excavations and correlations are key to long-term tsunami history.

This paper summarizes regional results from several recent field seasons, including sites spanning $400 \mathrm{~km}$ of Kamchatka's coastline, with the purpose of illustrating possi- 


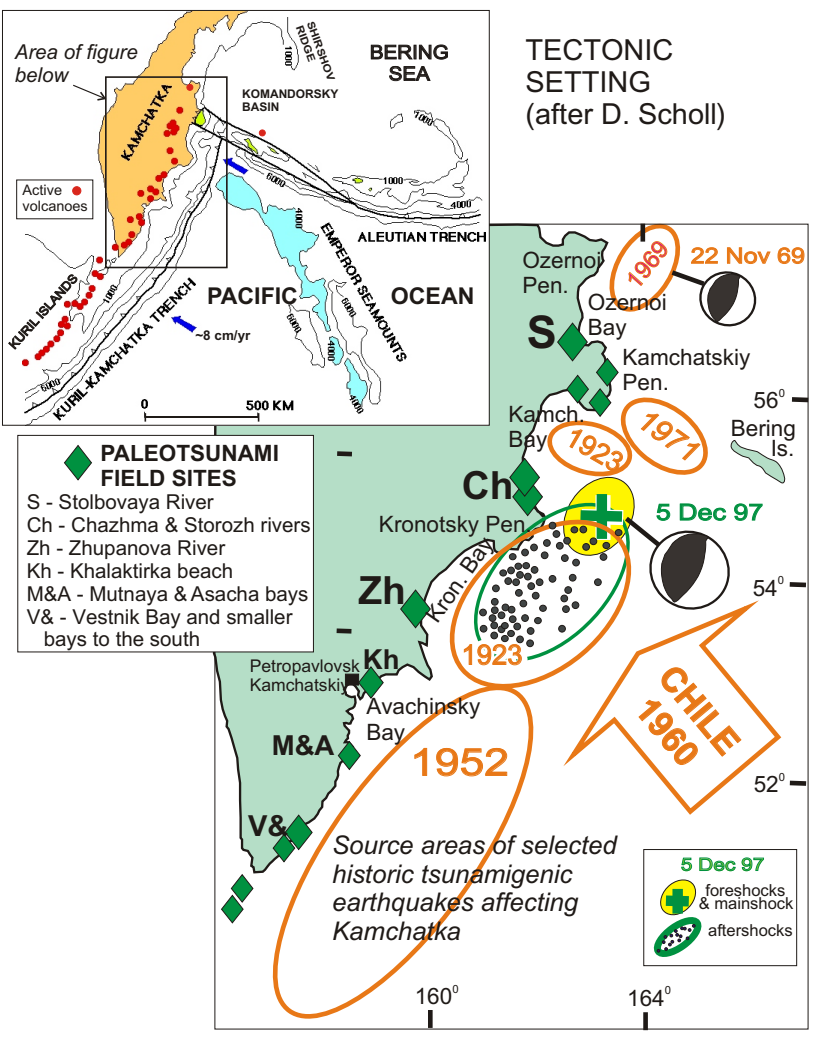

Fig. 1. Tectonic setting and field sites of our paleotsunami studies to date. Above: Tectonic setting of Kamchatka, in the northwestern Pacific (after D. Scholl). Below: Field sites of paleotsunami studies by our team, and source areas of selected historical tsunamigenic earthquakes (see Figs. 2 and 3). Other tsunami deposits illustrated in Fig. 2 include 1841, which was similar to 1923 Kronotsky Bay (south), and 1737, which was similar to 1952 , quite possibly larger.

bilities for regional correlation and analysis. To date, our published results have focused on southern Kronotskiy Bay (Zhupanova locality), site of Pinegina's dissertation research (Pinegina et al., 2002 and earlier publications). We are continuing to examine the recent and millennial-scale paleotsunami history of localities along the Kamchatka-Kuril subduction zone (Fig. 1), and more detailed studies are forthcoming. Our goals include finding and dating as many tsunami deposits as possible, so as to obtain statistically significant data for subduction-zone behaviour. We also are attempting to correlate the largest tsunamigenic events in this region (e.g. 1737 and 1952) over distances of hundreds of kilometers along this zone. Moreover, our investigations of deposits from historic tsunamis are helping to fill out the Kamchatka catalogue, and to evaluate tsunami behaviour.

\section{Background-setting, tephra, field methods}

\subsection{Setting of the field areas}

We have attempted to choose localities (as in Fig. 1) using the following criteria: (1) high seismicity (e.g. Vikulin, 1987;
Gorbatov et al., 1997) and a historic record of tsunamis; (2) historical tsunami deposits, which can be used as benchmarks; (3) peat marshes, which preserve tephra and tsunami deposits well, due to a high rate of peat accumulation, and (4) presence of well-studied tephra layers, so terraces and tsunami deposits may be dated and correlated.

We summarize here, very briefly, the setting of field localities noted on Figs. 1 and 2, from north to south. Ideal sections for our studies are in peat, as noted above. In general, all these localities have modern beach ridges with elevations of 4-8 $\mathrm{m}$, which tsunamis must surpass in order to leave deposits on the proximal coastal plain. For each site, corrections must be made for relative sea-level change since tsunami deposition (as in Pinegina et al., 2002, for the Zhupanova site). Unless otherwise noted, we use the elevation of marine (beach) sand below coastal soils to estimate paleosea-level elevation at the time of a tsunami.

The Stolbovaya River locality (south Ozernoi Bay, in the Bering Sea) is relatively stable tectonically, with little change in elevation relative to sea level for several thousand years (based on finding beach sediments below tephra at levels similar to the beach today). This coastline is an accretionary coastal plain; peat is locally present, but not common.

On the Kamchatskiy Peninsula (see Fig. 1), which in general is undergoing uplift and deformation associated with collision of the Aleutian-Komandorsky Island chain (Fig. 1) (Gaedike et al., 2000), we have done preliminary work at three localities, from north to south: Soldatskaya Bay, Cape Kamchatskiy, and Krutoberegovo. Only the section from Cape Kamchatskiy is illustrated herein (Fig. 2; see also Melekestsev et al., 1994). The Cape Kamchatskiy area (south Kamchatskiy Peninsula) is undergoing rapid uplift, and herein we discuss only historical events, so relative sealevel change is a minimal concern. Locally, beach ridges are well preserved; peat is rare.

The Chazhma-Storozh area (south Kamchatskiy Bay) is a long, relatively straight coastline of accretionary beach ridges fed by sediment from a series of rivers. The Chazhma area, just north of Kronotsky Peninsula, is undergoing uplift more rapidly than the Storozh area, $30 \mathrm{~km}$ to the north. Peat is not common near the shoreline in either locality, but key peat sections have been excavated. Detailed reconstruction of relative sea-level change along this shoreline has not yet been conducted.

The Zhupanova River locality (south Kronotsky Bay) can be divided into south and north areas: south of the mouth are a series of uplifted coastal terraces and rocky outcrops; north of the mouth is a series of accretionary beach ridges. Both north and south of the mouth are lagoons filling with peat since about 2000-4000 years ago. This area was the main focus of study by Pinegina for her dissertation (see references).

Khalaktirka Beach is a long, relatively straight and tectonically stable coastline consisting of accretionary beach ridges, with some lagoons. This site is important for hazard studies, but not ideal for paleotsunami work due to an 


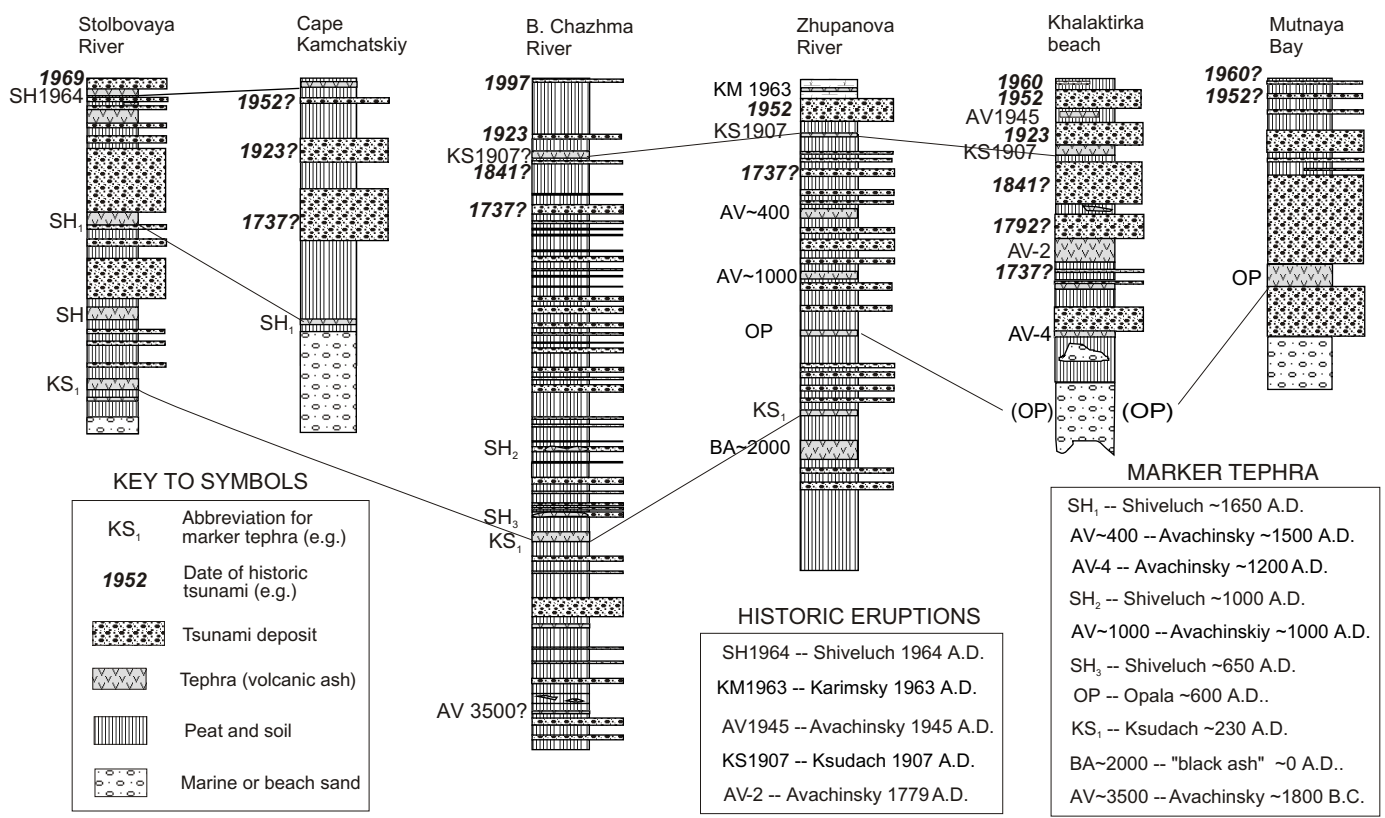

Fig. 2. Representative and in some cases composite stratigraphic sections from selected sites on Kamchatka (Fig. 1). Sections show tsunami deposits and tephra against background of soil or peat. Marker tephra are noted; in some cases these assignments are tentative, but the marker tephra used for correlation from locality to locality are well known.

over-abundance of coarse Avachinsky tephra, and to human disturbance. Peat is locally present.

Asacha and Mutnaya Bays are adjacent, open bays with rapid uplift and a series of stair-step coastal terraces; lagoons in these bays began to fill with peat about 2000 years ago. Analysis of relative sea-level change at these sites was conducted for Pinegina's dissertation (unpublished, in Russian).

In the summer of 2001, sites at Vestnik Bay and small bays farther south were examined. These bays are relatively stable tectonically, and consist of a series of accretionary beach ridges, many between 10 and $15 \mathrm{~m}$ in elevation. South of Kamchatka we have also done reconnaissance work on the northern Kuril Islands of Shumshu and Paramushir.

\subsection{Tephrostratigraphy}

Paleotsunami deposits on Kamchatka are assigned ages principally on the basis of their position with reference to known and dated volcanic ash (tephra) horizons (as in Fig. 2). There are on Kamchatka more than twenty-four Holocene keymarker tephra layers from eleven different volcanic centers (Braitseva et al., 1997). Ages of prehistoric marker tephra have been determined by multiple radiocarbon dates of enclosing strata, calibrated to calendar ages (Braitseva et al., 1997). These dated tephra layers provide a record of the most voluminous explosive events on Kamchatka. Each marker tephra has been traced for tens to hundreds of kilometers away from its source volcano and characterized by stratigraphic position, area of dispersal, radiocarbon age, typical grain-size distribution, and chemical and mineral composition. Marker tephra other than those in Braitseva et al. (1997), as well as more local ash layers, are used from locality to locality. Tephra are described and identified in the field, with these identifications checked by mineralogical examination of samples in the laboratory, and by consultation with tephrostratigraphers who have focused on that particular area. Local peat samples have been dated by bulk radiocarbon to help evaluate stratigraphy, but because correlation is key to our analysis, regional marker tephra are invaluable.

\subsection{Field methods and criteria for tsunami deposits}

Our results are based on summer field seasons from 1995 to 2000, about 10 major field sites, and over 500 stratigraphic sections from excavated trenches (as in Fig. 2; these illustrated sections are in some cases, composites of more than one excavation). Each section is measured and described stratigraphically; and in some cases sand and volcanic ash layers are sampled for granulometric and mineralogical analysis; peat is sampled in key excavations for radiocarbon dating. Most study-site excavations are located far and above places where sand could be transported by mechanisms other than a tsunami. Pits dug in hollows between beach ridges were not very useful because they are too sandy, with the sand mostly transported from the beach by wind and by storms as well as tsunami waves.

In the last ten years, deposits from a number of recent and historical tsunamis have been described (e.g. Clague et al., 1994; Sato et al., 1995; Nishimura and Miyagi, 1995; Minoura et al., 1996; see Dawson and Shi, 2000, for review). These observations have contributed to a general understanding of the nature of tsunami deposits, and criteria for their recognition. In general, tsunami deposits are sheet-like and consist of sediment eroded from adjacent beaches or other 
unvegetated surfaces. They can be locally patchy and will not be present over the entire inundated surface. Tsunamis can also produce erosion, particularly in proximal or unvegetated areas. Tsunami deposits commonly exhibit evidence of rapid deposition, such as grading or massive structure.

Tsunami deposits are not uniquely identifiable, and other kinds of deposits may share some of their characteristics, but in general will not share all. Storm deposits most closely resemble tsunami deposits, but storm waves will not penetrate the distances of a long wave such as a tsunami. Tsunami deposits will tend to show less contemporaneous reworking than storm deposits. Moreover, in the case of Kamchatka, cyclones are weaker than in Japan, for example, where tsunami deposits have been described to the exclusion of storms at elevations of less than $3 \mathrm{~m}$ (e.g. Minoura et al., 1994). Compared to tsunami and storm deposits, eolian sands are typically very well sorted, very fine sand, and form thicker, wedge-shaped layers; silt and very fine eolian sand are also disseminated in the peat. Flood deposits are typically browner and muddier, and fluvial sediment less mature than on the beach; moreover, most of our sites are not susceptible to river flooding. Colluvium is poorly sorted, with angular grains.

Our sections are principally located on coastal peat bogs and coastal terraces, $5 \mathrm{~m}$ or more above present sea level. The source of tsunami sediment for these sites is primarily beach sand eroded from the shoreline and deposited across vegetated surfaces. Sand layers are interpreted to be tsunami deposits based on the following characteristics. First, the sand layers are found beyond storm-wave influence; lack of storm-wave influence is identified by changes in vegetation from beach grasses to less tolerant plants; by elevation and distance from the shoreline, generally farther than $250 \mathrm{~m}$ and higher than $5 \mathrm{~m}$ from modern or reconstructed shorelines; and by the presence of (sand-poor) peat. Second, interpreted tsunami sands are similar to local beach sand, comprising generally well-sorted and well-rounded particles; these deposits usually become finer away from the coastline. Third, layers are sheet-like, with typical thicknesses of a few millimeters to a few centimeters, generally thinning away from the shoreline. Finally, the sand layers have a return period of decades to hundreds of years, as expected for tsunamis on a subduction-zone coastline.

\subsection{Estimating paleotsunami size}

We use the location and elevation of interpreted tsunami deposits as indicators of tsunami size. Tsunamis are generally characterized by runup, the elevation of the tsunami at maximum penetration, which in turn is defined as tsunami inundation. Our paleo-inundation distances are minima, because they are based on the presence of recognizable tsunami deposits, whereas tsunamis can penetrate farther than their deposits (e.g. Nishimura and Miyaji, 1995; Hemphill-Haley, 1996). Our paleo-elevation estimates are not technically runup because they do not represent an elevation at maximum penetration, they represent an elevation of a tsunami deposit at any location (thus they are better termed tsunami heights). We can nevertheless estimate runup by making excavations on successions of higher terraces.

In general, the east coast of Kamchatka is undergoing uplift, so that millennial-scale tsunami records are preserved in uplifted coastal terraces. For younger tsunamis, we can take the current elevation of the deposit as an indicator of runup, but for older tsunamis, we must take into account relative sea level changes. In addition, for older events, if we want to estimate inundation distances, we must estimate changes in the shoreline location due to sea-level changes or coastal accretion (or erosion). Even for young events, our estimates may be wrong if there has been abrupt uplift or subsidence associated with recent earthquakes. A key problem on Kamchatka is the paucity of documentation of co-seismic deformation from tsunamigenic (and other) earthquakes.

To date, detailed analysis of the relationship between tsunami deposits and relative sea level on Kamchatka has been completed only for the Zhupanova site (Pinegina et al., 2002). For other sites, this work is still in progress. Thus, in this paper we focus on frequency analysis rather than on tsunami magnitude.

\section{Records and deposits from historical earthquakes and tsunamis}

Kamchatka's historic record of tsunamis is short, but includes some large regional and local events (e.g. as on Fig. 1). In order to develop benchmarks for paleotsunami studies, it is instructive to examine the historical record of earthquakes and tsunamis for this region, and the deposits of those tsunamis. Moreover, with our field data and observations, we can help fill out and evaluate the historical catalogue for Kamchatka (as in Bourgeois and Pinegina, 2001). Since almost all of our sites are $5 \mathrm{~m}$ or more above sea level, we are usually looking at the record only of large tsunamis. We can ask, 'Which tsunamis in the historical period should have left deposits at our sites, and can we identify those deposits?' In evaluating the paleoseismicity of Kamchatka, we must also ask, 'How many of the deposits at each site may not be from locally generated tsunamis, but rather from fartraveled tsunamis (teletsunamis), for example, from Chile?'

\subsection{The historical tsunami record}

The most complete historical earthquake and tsunami record for Kamchatka is from the settlement of PetropavlovskKamchatskiy (Fig. 1), which is within Avachinsky Gulf (also called Avacha Bay in tsunami databases, and informally in English) and well protected from tsunamis. The most complete record on Kamchatka for a large tsunami is for the 1952 Kamchatka tsunami, one of the largest 20th century events in the world. This tsunami completely destroyed numbers of settlements in southern Kamchatka. The notorious 1737 tsunami was likely as large or larger than 1952. In addition, there are 14 locally strong tsunamis in the Kamchatka his- 
torical record. Moderate or weak tsunamis observed in the same period number 14, including some dubious events. In any case, the record is patchy, at best, until the 20th century, and even events as recent as 1997 have few recorded observations, on this remote coast (Zayakin and Pinegina, 1998; Bourgeois and Titov, 2001).

The 1960 Chile tsunami is the only teletsunami with recorded large runups on Kamchatka. Observations for Chile 1960 on Kamchatka are more limited than for Kamchatka 1952, partly because some towns were obliterated in 1952 and not rebuilt. Runups from Chile 1960 in our field areas (south and central east coast of Kamchatka) were, in general, about half the runup of the local 1952 tsunami, so we expect its deposits to be less extensive and less prominent than 1952 at study sites. Locally, we have found deposits we think we can attribute to 1960 Chile (see Fig. 2).

If we use the historical record from northern Japan as a proxy for earlier historical trans-Pacific tsunamis, 1960 was the only severe ( $>3 \mathrm{~m}$ runup) teletsunami on the Sanriku coast in the last 300 years (Minoura et al., 1994). We can also expect the 1700 Cascadia event to have produced no more than a moderate runup (1-3 m) on Kamchatka, and hence, not to have left deposits at most of our sites. Due to directivity, tsunamis from Alaska, such as 1964 and from all but the outermost Aleutians, do not produce significant runup on Kamchatka.

\subsection{Tsunami deposits in the historical period}

There are a number of historical tephra layers in our field sites, aiding in the identification of historical tsunami deposits (see Fig. 2). In some cases, we can be certain of given historical tsunami deposits, by using these tephra. In other cases, we can make likely guesses. These identifications help us both to evaluate and to expand on the historical catalogue, and also to use historic deposits as benchmarks for prehistoric (paleo-) tsunami deposits. Several examples follow; see also Fig. 2.

At Stolbovaya, the 1964 Shiveluch ash (SH 1964) underlies the 1969 (Ozernoi) tsunami deposit. We can rule out the Chile 1960 tsunami in this case because of the 1964 ash. Although runup from Chile in the Bering Sea was greater than runup from Kamchatka 1952, at Stolbovaya we can be confident that we are looking at the local 1969-tsunami deposit because of the presence of SH 1964. Moreover, the long tsunami-deposit record here suggests that the "fossil" subduction zone north of the Komandorsky Islands still produces tsunamigenic earthquakes.

Around Peninsula Kamchatskiy, there are few data from historical events. This area is a major tectonic boundary, and also a complex geomorphic feature. We have added data for some historical events in this area: 1737, April 1923, and 1952. Moreover, our observations lead us to believe that the 1936 catalogue event (Zayakin and Luchinina, 1987) is a spurious tsunami.

In the region of south Kamchatka Bay, there are few historical observations. Our work in progress (see section,
Bol'shaya Chazhma on Fig. 2) suggests that this area experiences high runups, and we suspect we have deposits here from several key historical events, including February 1923 (and possibly also April 1923), 1952, and most recently, December 1997. In the latter case, surveyed runup to the south was no more than $2 \mathrm{~m}$ (Zayakin and Pinegina, 1998), so runup indicators of $5 \mathrm{~m}$ or more in the Chazhma River area are an important result (Bourgeois and Titov, 2001).

At the Zhupanova site, only one tsunami deposit lies between the KM 1963 and the KS 1907 tephra, and we attribute this layer to the 1952 Kamchatka tsunami. We reject the alternative sources - 1923 Kamchatka and 1960 Chile - because in the former case, the deposit is high in the section (close to 1963), and in the latter case, the tsunami was only about half as large as 1952. The absence of a deposit from the 4 February 1923 tsunami indicates that local runup from this event was probably less than $5 \mathrm{~m}$. In the last 500 years (since AV 400), the Zhupanova River locality experienced at least six tsunamis with runup of 4 to $5 \mathrm{~m}$ or more. For this location, historic records describe only one of these events, the 1952 tsunami.

At Khalaktirka, the 1945 Avachinsky (AV 1945) and 1907 Ksudach (KS 1907) tephra are locally present, as well as the "Cook" tephra, 1779 Avachinsky (AV-2). We believe we can identify tsunami deposits at Khalaktirka from 1960, 1952, February 1923, 1841, and 1737 . We question the catalogue runup number of $15 \mathrm{~m}$ for Khalaktirka in 1841, because the deposit in that stratigraphic position is comparable to 1952, which had a runup of about $5 \mathrm{~m}$ at Khalaktirka.

In Mutnaya and Asacha Bays, runup and inundation, as indicated by tsunami deposits are larger than expected from the historical catalogue. Moreover, the differences in tsunami deposits between these two bays provide an interesting contrast, controlled primarily by geomorphology. For example, the 1952 tsunami deposit in Mutnaya Bay was found $12 \mathrm{~km}$ upriver ( $3 \mathrm{~m}$ elevation), whereas in Asacha Bay, penetration reached about $2.5 \mathrm{~km}$ ( $5 \mathrm{~m}$ elevation). This work is in progress.

In south Kamchatka and the northern Kurils, we are particularly interested in reconstructing the two largest historical local events - 1737 and 1952. This work is challenging, because most historical marker tephra have been distributed more toward the north, and the tephrostratigraphy of this region is not completed. Nevertheless, we are confident in most localities that we can identify the 1952 tsunami deposit, and in most cases, we have "candidate" deposits for 1737, as well as other historical events.

\section{Tsunami deposits on a millennial time scale}

With some confidence from the historical record, we can extend our analysis back several millennia (Pinegina et al., 2000; Pinegina et al., 2002). Key to our analysis is the presence of marker tephra for correlation, as well as for age control. Less important than the precise age of these tephra is the fact that they are time lines. Most of our sections cover at 

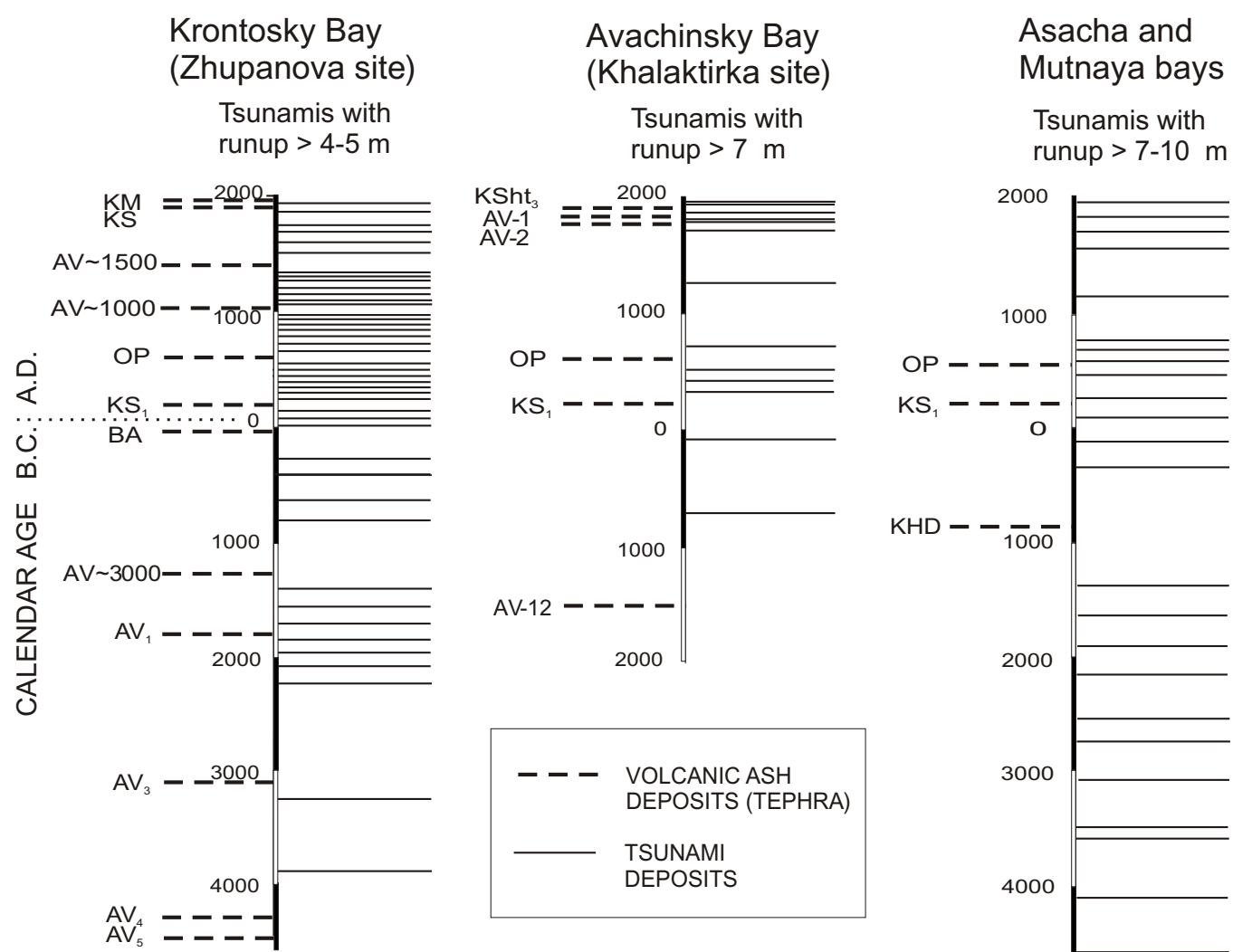

\footnotetext{
KM -- Karimsky 1963 A.D.

$\mathrm{KSht}_{3}$-- Ksudach (Shtyubel cone) 1907 A.D.

AV-1 -- Avachinsky 1855 A.D.

AV-2 -- Avachinsky 1779 A.D. ( Cook tephra)

¿ $\quad$ AV 1500 --Avachinsky $\left(\sim 400{ }^{14} \mathrm{C}\right.$ yr B.P.)

$\nsubseteq \quad$ AV $\sim 1000--$ Avachinsky $\left(\sim 1000{ }^{14} \mathrm{C}\right.$ yr B.P. $)$

I OP -- Opala (Baraniy Amphitheater) $\sim 600$ A.D.

KS 1 -- Ksudach 230 A.D.

WA -- "black ash" of unknown source, $\sim 2000{ }^{14} \mathrm{C}$ yr B.P.
$-\quad$ KHD -- Khodutkinskiy maar $\sim 2800(2500 ?){ }^{14} \mathrm{C}$ yr B.P.

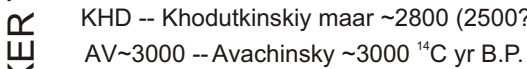

AV 3000 --Avachinsky $\sim 3000{ }^{14} \mathrm{C}$ yr B.P.
AV-12 -- Avachinsky $\sim 1500$ B.C. $~ 3200{ }^{14} \mathrm{C}$ yr B.P.

$\stackrel{\text { q }}{\sim} \quad A V_{1}-$ - Avachinsky $\sim 3500{ }^{14} \mathrm{C}$ yr B.P.

$\sum \quad \mathrm{AV}_{3}-$ - Avachinsky $\sim 4500{ }^{14} \mathrm{C}$ yr B.P.

$\mathrm{AV}_{4} \& \mathrm{AV}_{5}$-- Avachinsky $\sim 5500 \& \sim 5600{ }^{14} \mathrm{C}$ yr B.P.

$\mathrm{KS}_{2} \& \mathrm{KS}_{3}$-- Ksudach caldera IV $\sim 6000-6100{ }^{14} \mathrm{C}$ yr B.P.

KO -- Kuril Lake caldera $\sim 7600{ }^{14} \mathrm{C}$ yr B.P.

$\mathrm{KC}_{4}$-- Ksudach caldera III $\sim 8800{ }^{14} \mathrm{C}$ yr B.P.
}

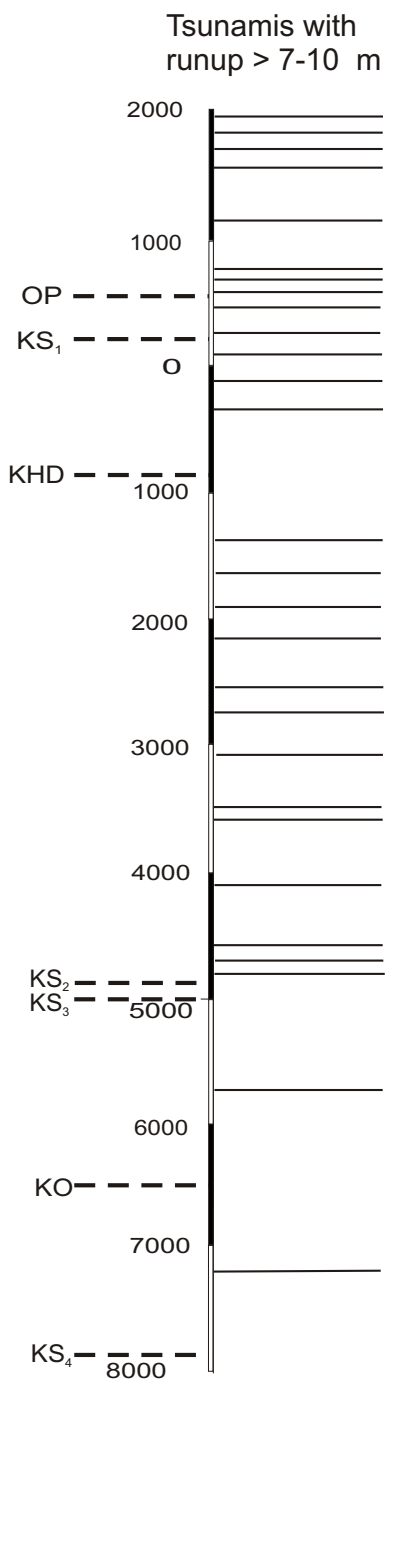

Fig. 3. Millennial-scale chronology for tsunamis for three localities on Kamchatka (see Fig. 1). Variation in chronology is affected by preservation factors, as well as local topographic differences (the latter noted at the top of the column). Age assignments of marker tephra are subject to revision and can affect frequency analysis. Moreover, apparent frequency appears to decrease with time from the present, primarily due to preservation factors and also to number of observations. Nevertheless, the Zhupanova site shows particularly well an increase in tsunami-deposit frequency in the period of about 0 to 1000 A.D.

least the last 2000 years, and many sections go back about 4000 years. The oldest excavations contain tephra as old as 8000 years. After we compile stratigraphic sections and identify tephra layers, we correlate the sections, first locally, and produce composite sections. Then we calculate the total number of tsunamis from the maximum number of deposits recorded within each time interval, as delimited by tephra. That is not to say that we take into consideration all the tsunami events in the region, as is shown in our discussion of the historical record. Moreover, not all sections contain the same number of tsunami deposits, due to a number of depositional and preservational factors. Our experience would suggest that tens of excavations are necessary in any one locality, in order to generate a substantial record of prehistoric tsunamis. 
4.1 Examples of and problems with long-term chronologies

Figure 3 illustrates three summary long-term chronologies, correlated with regional marker tephra. Age assignments are approximate, and subject to revision, but what is most important for our work is that the tephra represent time markers, and can be used for correlation from section to section and from locality to locality. From these data we can evaluate tsunami frequency and compare different sites.

Factors that must be considered in analyzing and comparing long-term chronologies include: (1) preservation of tsunami deposits (and tephra) - better, for example in peat sections, and better in younger deposits; also, better separation of individual tsunami deposits at intermediate distances from the shore (varying from locality to locality, depending on scaling of tsunamis, and morphology of the coastline); (2) number of observations - in general, the number of excavations exposing a given time interval decreases with older stratigraphy; for example in 20 excavations, 18 may record at least 1000 years, 12 might record 2000 years, 7 might record up to 3000 years, with a few excavations going back 5000 years or more (up to 8000 years); (3) coastal morphology and local topography where some sites are as low as $3-5 \mathrm{~m}$ above sea level; most are more than $5 \mathrm{~m}$ above sea level; 'How can we compare frequencies when different sites are at different elevations and distances from the shoreline?' - in most cases, we measure profiles perpendicular to the shoreline and excavate multiple trenches along this profile, which partly alleviates this problem; (4) history of coastal accretion and relative sea-level changes - these factors must be addressed on a site-by-site basis; and (5) variance in the "real" record - the historical record, although short, shows that different parts of Kamchatka are characterized by different scales of tsunamis; comparison of frequency from site to site should take this into account.

\subsection{Statistical age determination}

Our analyses use only known and well-dated tephra. We are attempting to assign more accurate ages to each tsunami by graphical statistical techniques. This work is most possible in peat sections, because it is fair to assume that peat accumulation rates vary slowly and continuously and can be approximated by ages of bounding tephra. However, intervening tsunami layers and tephra are deposited instantaneously, and if they are thick or otherwise noxious, they can for some time inhibit peat growth. Tsunamis deposits preserved in terrace soils are more difficult to work with. Moreover, we know that tsunami deposits within the historical period can vary significantly in their position in different sections, and that peat accumulation rates vary from section to section, so that correlation of individual events can be a challenge, even in the historical period.

On the basis of our composite sections and key-marker tephra, we can construct summary catalogues of tsunamis (in general, with runup of more than $5 \mathrm{~m}$ ), for our various localities (as in Fig. 3). Data in the catalogue are most complete for the last 2000 years, and reasonably complete for the last 4000 years. For older times, only the largest events, as recorded in older, generally uplifted terraces, are preserved. We are attempting to adjust our statistical data for preservational and observational biases, to include the older, less abundant records. This analysis has been completed only for the Zhupanova site (Pinegina et al., 2002).

\subsection{Results to date}

The data thus far obtained suggest some relationships between tsunami frequency and tsunami intensity, as well as between the tsunami wave height as its approaches the coast and tsunami inundation distance. For example, in the region of the Zhupanova River mouth, tsunamis about $5 \mathrm{~m}$ high occurred 12 times per 1000 years on the average during the last 3000 years. In those cases, the waves reached as far as $1 \mathrm{~km}$ from the coast. Tsunamis of about $30 \mathrm{~m}$ height occurred only once about every thousand years, with the maximum distance of penetration being $10 \mathrm{~km}$ (Pinegina et al., 2000).

In central Kamchatka, over the last 3000-4000 years, it appears that tsunamis became more frequent within the interval 2000 to 1000 years ago. About the same time (1800-1300 years ago) there was an upsurge of volcanic activity (Braitseva et al., 1995; see also Gusev et al., accepted). It might be argued that the increase in frequency in these sections is a matter of increased preservation toward the present day, and perhaps only further examination of older sections will be convincing. The repetition of this trend in separate localities, and the apparent decrease in frequency in the last millennium lead us to believe this trend may be real.

These kinds of data also help us to understand tsunami behaviour and thus contribute to modeling of tsunami runup. For example, the Mutnaya and Asacha bays are only $5 \mathrm{~km}$ apart, and yet tsunami inundation in Mutnaya Bay is on the order of five times greater than in Asacha Bay. In at least two of our field cases (Stolbovaya and Chazhma areas), we have evidence of large tsunami runup for earthquakes that are not well understood (1969 and 1997). These data will help us to generate source models for these earthquakes and associated tsunamis (Bourgeois et al., 1999, 2001).

\section{Discussion}

The study of tsunami deposits is one of the most reliable ways to reconstruct the pre-historic seismic behaviour of subduction zones. Another paleoseismic indicator is tectonically induced and hence sudden land-level change, such as buried soils used for the Cascadia subduction zone (Atwater and Hemphill-Haley, 1997). However, along many subduction zones, interseismic and net uplift mask this record. Moreover, the suddenness of land-level change can be called into question unless there is other evidence of the earthquake, such as contemporaneous liquefaction features, landslides, or - a key indicator of sudden sub-sea movement - tsunami 
deposits. Compared to tsunami deposits and buried soils, other paleoseismic indicators such as liquefaction features and landslides are more patchy, less strata-bound, and more difficult to date. Furthermore, landslides are not generated exclusively by earthquakes.

Tsunamis are also not produced exclusively by earthquakes; they may be generated by submarine landslides and volcanic eruptions, and by large-body impacts with water. However, nearly all historic, regionally large events are associated with earthquakes, and the largest of these with subduction-zone earthquakes. These largest events (e.g. Kamchatka 1952, Chile 1960, Alaska 1964) produce significant trans-oceanic runup, so in order to reconstruct local subduction-zone history, we must factor out far-traveled tsunamis. Distinguishing deposits of local vs. teletsunamis remains a challenge.

Dating and correlation of events are also keys to and challenges in producing accurate and long-term histories. On Kamchatka, the presence of abundant tephra, and also of datable peat, permit the possibility, but careful and laborious study is required, and thus results presented herein should be considered preliminary. We believe we are detecting centuries- to millennial-scale variations in subduction-zone activity, both in time and space, and we are attempting to quantify this variation. We are also working to quantify the relationship between tsunami deposit and tsunami size, and hence earthquake characteristics.

Tsunami deposits are not only a key to prehistoric events, but they can help us reconstruct and understand historic events. Such studies are particularly important in regions with short or patchy (temporal or geographic) history. The study of historic events and their records is, in turn, a key to reconstructing the prehistoric record. Since tsunamis are a significant natural hazard not only around the Pacific Rim, but also particularly in the Mediterranean and Caribbean regions, tsunami-deposit studies can help save lives.

Acknowledgements. This work could not be accomplished without the outstanding tephrostratigraphy group of the Institute of Volcanic Geology \& Geochemistry, including O. Braitseva, I. V. Melekestsev, V. Ponomareva, and L. Bazanova. Ponomareva and Bazanova have spent significant time in the field with us. Field assistance and advice were provided in particular by A. Storcheus, R. Spitsa, and I. Storcheus; a host of other field assistants and coordinators also deserve our thanks.

This research has been supported by a number of grants from the Russian Foundation for Fundamental Research, as well as funding from the U.S. National Science Foundation (to Bourgeois) and the National Geographic Society (to Ponomareva).

\section{References}

Atwater, B. F. and Hemphill-Haley, E.: Recurrence intervals for great earthquakes of the past 3500 years at northeastern Willapa Bay, Washington, U.S. Geological Survey Professional Paper, 1576, 108, 1997.
Benson, B. E., Grimm, K. A., and Clague, J. J.: Tsunami deposits beneath tidal marshes on northwestern Vancouver Island, British Columbia, Quaternary Research, 48, 2, 192-204, 1997.

Bourgeois, J. and Pinegina, T. K.: Tsunami deposits on Kamchatka, Russia: Contributions to historical and millennial-scale recordswork in progress, Proceedings of Tsunami Risk Workshop, Theory Practice and Plans, Moscow, Russia, June 2000, (Ed) Gusiakov, V. K., 2001.

Bourgeois, J. and Titov, V. V.: A fresh look at the 1997 Kronosky tsunami: Transactions of the European Geophysical Society, Abstracts, 2001.

Bourgeois, J., Pinegina, T. K., Titov, V., Landis, S., and Mann, C.: Bathymetric and topographic effects of the 1969 Ozernoi tsunami: runup evidence from tsunami deposits at Stolbovaya, Kamchatka, Russia, Eos (Transactions, AGU), 80, 46, F751. 1999.

Bourgeois, J., Pinegina, T. K., and Titov, V. V.: Can the study of tsunami deposits help us understand historic events? Example of 1969 Ozernoi, Kamchatka, and others: Tsunami Risk International Workshop, Moscow, Russia, 14-16 June 2000, abstracts, 25, 2001.

Braitseva, O. A., Melekestsev, I. V., Ponomareva, V. V., and Sulerzhitsky, L. D.: Ages of calderas, large explosive craters and active volcanoes in the Kuril-Kamchatka region, Russia, Bulletin of Volcanology, 57, 383-402, 1995.

Braitseva, O. A., Ponomareva, V. V., Sulerzhitsky, L. D., Melekestsev, I. V., and Bailey, J.: Holocene key-marker tephra layers in Kamchatka, Russia, Quaternary Research, 47, 125-149, 1997.

Clague, J. J., Bobrowsky, P. T., and Hamilton, T. S.: A sand sheet deposited by the 1964 Alaska tsunami at Port Alberni, British Columbia, Estuarine, Coastal and Shelf Science, 38, 4, 413-421, 1994.

Dawson, A. G., Foster, I. D. L., Shi, S., Smith, D. E., and Long, D.: The identification of tsunami deposits in coastal sediment sequences, Science of Tsunami Hazards, 9, 1, 73-82, 1991.

Dawson, A. G. and Shi, S.: Tsunami deposits, Pure and Applied Geophysics, 157, 875-897, 2000.

Gaedicke, C., Baranov. B., Seliverstov, N., Alexeiev, D., Tsukanov, N., and Freitag, R.: Structure of an active arc-continent collision area: the Aleutian-Kamchatka junction, Tectonophysics, $325,1 / 2,63-85,2000$.

Gorbatov, A., Kostoglodov, V., Suarez, G., and Gordeev, E.: Seismicity and structure of the Kamchatka subduction zone, J. Geophys. Res., 102, 17 883-17 898, 1997.

Gusev, A. A., Ponomareva, V. V., Braitseva, O. A., Melekestsev, I. V., and Sulerzhitsky, L. D.: Great explosive eruptions on Kamchatka in the last 10000 years: Fractal irregularity of the output of volcanic products, J. Geophys. Res., accepted.

Hemphill-Haley, E.: Diatoms as an aid in identifying late-Holocene tsunami deposits, The Holocene, 6, 4, 439-448, 1996.

Melekestsev, I. V., Kurbatov, A. V., Pevzner, M. M., and Sulerzhitsky, L. D.: Prehistoric tsunamis and large earthquakes on the Kamchatskiy Peninsula, Kamchatka, based on tephrochronological data, Volcanology and Seismology, 16, 449-459, 1994.

Minoura, K., Nakaya, S., and Uchida, M.: Tsunami deposits in a lacustrine sequence of the Sanriku coast, northeast Japan, Sedimentary Geology, 89, 1/2, 25-31, 1994.

Minoura, K., Gusiakov, V. G., Kurbatov, A., Takeuti, S., Svendsen, J. I., Bondevik, S., and Oda, T.: Tsunami sedimentation associated with the 1923 Kamchatka earthquake, Sedimentary Geology, 106, 1/2, 145-154, 1996.

Nishimura, Y. and Miyaji, N.: Tsunami deposits from the 1993 
Southwest Hokkaido earthquake and the 1640 Hokkaido Komagatake eruption, northern Japan. In: Tsunamis; 1992-1994, their generation, dynamics, and hazard, (Eds) Satake-Kenji and Imamura-Fumihiko, Pure and Applied Geophysics, 144, 3/4, 719-733, 1995.

Pinegina, T. K., Melekestsev, I. V., Bazanova, L. I., Braitseva, O. A., and Storcheus, A. V.: East Kamchatka paleotsunami traces (in Russian), Priroda Magazine of R.A.S., N6, 102-106, 1997.

Pinegina, T. K., Bazanova, L. I., Melekestsev, I. V., Braitseva, O. A., Storcheus, A. V., and Gusiakov, V. K.: Prehistorical tsunamis on the shores of Kronotsky Bay, Kamchatka, Russia: a Progress Report (in Russian), Volcanology and Seismology, N2, 66-74, English edition, Volcanology and Seismology, 22, 213-226, 2000.

Pinegina, T. K., Bourgeois, J., Bazanova, L. I., Melekestsev, I. V., and Braitseva, O. A.: A millennial-scale record of Holocene tsunamis on the Kronotskiy Bay coast, Kamchatka, Russia, Quaternary Research, 2002.

Sato, H., Shimamoto, T., Tsutsumi, A., and Kawamoto, E.: Onshore tsunami deposits caused by the 1993 Southwest Hokkaido and
1983 Japan Sea earthquakes, (in Tsunamis 1992-1994), Pure and Applied Geophysics, 144, 3/4, 693-717, 1995.

Soloviev, S. L. and Go, C. N.: Catalogue of tsunamis on the western shore of the Pacific Ocean (in Russian): Moscow, Russia, 308, 1974.

Vikulin, A. V.: Special features of earthquake distribution in the northwestern Pacific (in Russian), Petropavlovsk-Kamchatskiy, Russia, 54, 1987.

Zayakin, Y. A.: Tsunamis in Far Eastern Russia (in Russian): Petropavlovsk-Kamchatskiy, 86, 1996.

Zayakin, Y. A. and Luchinina, A. A.: Catalogue of tsunamis on Kamchatka (in Russian): Vniigmi-Mtsd, Obninsk, Russia, 50, 1987.

Zayakin, Y. A. and Pinegina, T. K.: Tsunami on Kamchatka, 5 December 1997 (in Russian with English abstract and figure captions) in: Kronotskoye earthquake of 5 December 1997 on Kamchatka: precursors, particulars and consequences, (Eds) Gordeev et al., Russian Acad. of Sciences, 257-263, 1998. 